\title{
Kinetics of attachment of potentially toxic bacteria to Alexandrium tamarense
}

\author{
Nathalie Simon ${ }^{1, *}$, Isabelle C. Biegala ${ }^{1}$, Elizabeth A. Smith ${ }^{2}$, Daniel Vaulot ${ }^{1}$ \\ ${ }^{1}$ Station Biologique de Roscoff, UMR 7127, CNRS et Université Pierre et Marie Curie, BP 74, 29682 Roscoff Cedex, France \\ ${ }^{2}$ Fisheries Research Services, Marine Laboratory, PO Box 101, Victoria Road, Aberdeen AB11 9DB, Scotland, UK
}

\begin{abstract}
Interactions between bacteria and harmful algae are potentially important regulating factors for population dynamics of both organisms and for toxin production. These interactions are still poorly understood. To monitor the physical associations between potentially toxic bacteria and dinoflagellates in controlled conditions, we inoculated an axenic non-toxic strain of Alexandrium tamarense (Dinophyceae) together with reputed paralytic shellfish toxin (PST)-producing bacteria belonging to the genus Alteromonas ( $\gamma$ subdivision of the division Proteobacteria) and to the clade Roseobacter ( $\alpha$ subdivision of the division Proteobacteria). The attachment behavior of both bacterial strains was monitored using TSA-FISH (tyramide signal amplification and fluorescent in situ hybridization) and confocal microscopy. Our results suggest that ageing dinoflagellate cultures stimulate both free bacterial growth and attachment. However, toxin production by originally non-toxic dinoflagellate cells was not induced by the physical interaction of either of the bacterial strains with the dinoflagellate cells. This does not support the hypothesis that toxic bacteria could simply control toxin production by attachment to particle surfaces such as eukaryotic organisms.
\end{abstract}

KEY WORDS: Attached bacteria $\cdot$ Dinoflagellate $\cdot$ Alexandrium $\cdot$ Bacteria-phytoplankton interactions $\cdot$ In situ hybridization · Tyramide signal amplification $\cdot$ Confocal micoscopy

\section{INTRODUCTION}

The relationships between phytoplankton and bacteria in the aquatic environment play a crucial role in important processes such as carbon fluxes and nutrient regeneration (Cole et al. 1988, Azam 1998). Major fluxes of organic matter produced by phytoplankton are transferred via dissolved organic matter (through exudates and leakage from broken cells) to bacteria and the microbial loop (Azam 1998), while remineralisation by bacteria supplys nutrients to phytoplankton. Bacteria and phytoplankton cells can also compete in conditions where nutrients are limiting for both organisms (Cole 1982, Gurung et al. 1999). In addition, phytoplankton cells and bacteria can release antagonistic or stimulating substances such as antibiotics or vitamins (Cole 1982, Manage et al. 2000). Interactions

*E-mail: simon@sb-roscoff.fr such as these are of prime importance in the regulation of algal populations.

In the context of toxic events and blooms, bacterialalgal interactions may also be involved in the induction and control of toxin production. Osada \& Stewart (1997) suggested the indirect involvement of non-toxic bacteria in the enhancement of the production of the toxin domoic acid by the diatom Pseudo-nitzschia multiseries. In this case, bacteria, through the production of gluconic acid that reportedly shows powerful sequestering properties for nutrients, are thought to induce the algae to produce domoic acid, which is argued to be a counter chelating agent. The role of bacteria in the production of paralytic shellfish toxins (PST) by Alexandrium spp. has been highly debated. The demonstration of PST production after inoculation of a bacterial strain into non-toxic dinoflagellate cultures (Silva \& Sousa 1981, Silva 1990), the modification of the toxin profile after a bactericidal treatment of a toxic dinoflagellate culture (Hold et al. 2001) and the 
autonomous bacterial production of phycotoxins (Gallacher et al. 1997, Doucette et al. 1998) has, in some cases, cast doubt that these toxins are indeed produced by the algae alone (see reviews by Rausch de Traubenberg \& Lassus 1991, Doucette et al. 1998). Nevertheless, several authors have reported on the production of PST by 'axenic' dinoflagellate cultures with levels of toxicity similar to those observed for non-axenic strains (Dantzer \& Levin 1997, John \& Flynn 1999) but the absence of bacteria (free, attached or endocellular) was not clearly demonstrated. Tosteson et al. (1989) and Doucette et al. (1998) suggested that bacteria could modify algal toxicity via attachment. However, mechanisms by which physical interactions can influence toxin production levels for the partners of the bacteria-dinoflagellate association remain unknown. Indeed, techniques have been lacking to identify specifically the bacteria associated to Alexandrium spp. and to study their spatial relationships.

Bell \& Mitchell (1972) created the term 'phycosphere' to qualify a zone surrounding algal cells in which bacteria are influenced by algae and conversely algae by bacteria. Bacteria can be free in the phycosphere (Blackburn et al. 1998), attached to the surface of algal cells (Kogure et al. 1982, Vaqué et al. 1990, Worm \& Sondergaard 1998) or intracellular (Silva \& Franca 1985, Lewis et al. 2001). Few investigators have examined the process of attachment to algal cells (Kogure et al. 1982, Vaqué et al. 1990, Worm \& Sondergaard 1998). Methods used by these authors have included phase contrast and epifluorescence microscopy to directly detect and enumerate attached bacteria on algal cell surfaces, with a preliminary filtration or centrifugation step sometimes used to exclude free bacteria. Indirect methods have also been proposed, with the number of attached bacteria estimated by subtracting the total number of bacteria collected before and after chemical treatment and sonication of cultures (Albright et al. 1986). These treatments dispersed attached bacteria in the medium. Biegala et al. (2002) recently proposed a method involving fluorescent in situ hybridization with group-specific oligonucleotide probes and tyramide signal amplification (TSA-FISH), used in conjunction with confocal laser scanning microscopy (CLSM) to monitor bacterial attachment to phytoplankton cells. This method presents several advantages. First, individual bacterial strains can be distinguished in a mixture of taxa and their specific behavior can be monitored. Second, with CLSM, attached bacteria surrounding the entire cell (including in the sulcus and cingulum) can be enumerated (while only the top half of the cell can be examined using epifluorescence microscopy) and intracellular bacteria can be detected.
To study toxic bacteria-dinoflagellate interactions in controlled conditions, we incubated an axenic nontoxic strain of Alexandrium tamarense with bacterial isolates belonging or closely related to the genera Alteromonas and Roseobacter (respectively $\gamma$ and $\alpha$ subdivisions of the Proteobacteria). Previous mouse neuroblastoma (MNB) assays suggested that these bacteria, isolated from toxic Alexandrium strains, were capable of synthesizing sodium channel blocking (SCB) toxins (Gallacher et al. 1997, Gallacher \& Smith unpubl. data). The chemical nature of the toxins was determined in the Alteromonas isolate as PST by high performance liquid chromatography (HPLC) and capillary electrophoresis-mass spectrometry (CE-MS) (Gallacher et al. 1997). Both the genera Alteromonas and Roseobacter are common in marine environments and are frequently found in association with algae (Lafay et al. 1995, Holmström \& Kjelleberg 1999). The questions we addressed were: (1) Do potentially toxic bacterial isolates attach to dinoflagellates? (2) What is the specific attachment behavior of those bacterial strains? (3) Does attachment of potentially toxic bacteria to cells of $A$. tamarense induce the algal cells to produce PSTs? Using fluorescent whole-cell hybridization with group-specific oligonucleotide probes and confocal microscopy, we were able to monitor the physical association of each potentially toxic bacterial strain to A. tamarense cells throughout the dinoflagellates' growth. The ability of these bacteria to induce detectable toxin production by the algae, especially through attachment to the cells, was also tested.

\section{MATERIALS AND METHODS}

Strains and cultivation. An axenic non-toxic culture of Alexandrium tamarense (strain CCMP 1771, Provasoli-Guillard Culture Center for Marine Phytoplankton, Boothbay Harbor, ME, USA), and 2 different bacterial strains (253-11 and 407-2 provided by the Fisheries Research Services, Marine Laboratory, Aberdeen, UK) were investigated in this study. The bacterial strain 253-11 belongs to the Roseobacter clade ( $\alpha$-Proteobacteria) and was isolated from toxic Alexandrium lusitanicum (NEPCC 253, North East Pacific Culture Collection, Vancouver, BC, Canada) whereas 407-2 belongs to the genus Alteromonas ( $\gamma$-Proteobacteria) and was isolated from toxic $A$. tamarense (NEPCC 407; Gallacher et al 1997). Both 407-2 and 253-11 isolates had been previously shown to produce SCB toxins (Gallacher et al. 1997, S. Gallacher pers. comm.). Inocula of dinoflagellate and bacterial strains were prepared respectively in Guillard's f/2 medium (Sigma-Aldrich) and marine broth (DIFCO). Autoclaved and sterile filtered natural seawater collected 
off Roscoff was used to prepare the $\mathrm{f} / 2$ medium. Bacteria were cultured in the dark at $15^{\circ} \mathrm{C}$ in polycarbonate $10 \mathrm{ml}$ tubes (Nalgene) whereas dinoflagellates were grown in 11 polycarbonate bottles (Nalgene) at $15^{\circ} \mathrm{C}$, under a light:dark cycle of 14:10 h, with an intensity of $54 \mu \mathrm{mol}$ photons $\mathrm{m}^{-2} \mathrm{~s}^{-1}$.

Experimental conditions and sampling. Prior to inoculation in f/2 medium, bacteria (strains 253-11 and 407-2 in late exponential growth phase) were pelleted $(600 \times g, 3 \mathrm{~min})$ and washed in $\mathrm{f} / 2$ medium. Three different combinations of cell association were tested: Alexandrium tamarense and 253-11, A. tamarense and 407-2, A. tamarense with both 253-11 and 407-2. In addition, 4 control cultures were prepared: A. tamarense alone, 253-11 alone, 407-2 alone or 253-11 together with 407-2. All cultures (1 1 each) were monitored for $34 \mathrm{~d}$. Sampling $(1 \mathrm{ml})$ for cell enumeration by flow cytometry was performed every other day for the first $2 \mathrm{wk}$ and then every week. Samples were fixed with $0.25 \%$ glutaraldehyde, frozen in liquid nitrogen and stored at $-20^{\circ} \mathrm{C}$ until further analysis. For FISH (fluorescent in situ hybridization), sampling (10 to $20 \mathrm{ml}$ ) was achieved every $4 \mathrm{~d}$ for the first $2 \mathrm{wk}$ and then every week. Samples were fixed with $1 \%$ paraformaldehyde at $4^{\circ} \mathrm{C}$ for $24 \mathrm{~h}$, immobilized onto inorganic filter membranes (Anodisc, Whatman), dehydrated in an ethanol series (50, 80, 100\%, 3 min each; Amann 1995), dried and kept at room temperature in the dark until FISH was performed.

Flow cytometry. Dinoflagellates and total free-living bacteria were enumerated using a FACSort flow cytometer (Becton Dickinson). Dinoflagellates were identified according to their red autofluorescence and their scattering properties, whereas bacteria were stained with SYBR Green I (Molecular Probes) prior to analysis (Marie et al. 1997).

Probes. Oligonucleotide probes (Table 1) were purchased with a $5^{\prime}$-aminolink (C6) from Interactiva and labeled with the enzyme horseradish peroxidase (HRP, Boehringer Mannheim) according to Urdea et al. (1988) and Amann et al. (1992). ROSEOC536R was used as a competitor (Manz et al. 1992) and was not labeled with HRP.
Fluorescent in situ hybridization. In situ hybridization with TSA amplification was performed according to the protocol described by Biegala et al. (2002) modified from Schönhuber et al. (1999). Briefly, the bacterial cell wall is permeabilized with lysozyme prior to hybridization with HRP-labeled probes. Probes in excess are removed by several washing steps and cells are further incubated in a buffer containing fluorophore-labeled tyramides $\left(\mathrm{TSA}^{\mathrm{TM}}\right.$-Direct kit, NEN ${ }^{\mathrm{TM}}$ Life Science Product). HRP catalyzes the rapid deposition of fluorophore-tyramides in the close environment of the enzyme. To identify bacterial types in mixed cultures, a double hybridization was performed (Biegala et al. 2002). The HRP-labeled probes AMAC137R and EUB338R were used successively in combination with tyramide-fluorescein and tyramide-coumarin as substrates for HRP. To monitor bacterial attachment onto dinoflagellate theca, a single hybridization was performed either with AMAC137R or ROSEO536R together with the competitor ROSEOC536R. For single hybridizations, tyramide-fluorescein was used as the substrate for HRP and cells were then further stained with the DNA-specific dye DAPI $\left(4^{\prime}, 6\right.$-diamidino-2phenylindole, Sigma-Aldrich) and the cellulose specific dye calcofluor (Sigma-Aldrich) as described in Biegala et al. (2002). Calcofluor stained the dinoflagellate theca and helped to visualize precisely bacterial attachment, whereas DAPI served to visualize the nucleus. Both dyes helped distinguish morphologically intact cells from empty theca and broken cells. DAPI staining and in situ hybridization with TSA amplification and the general eubacterial probe also allowed us to confirm the axenic status of the dinoflagellate strain chosen in this study; no free, attached or intracellular bacteria were observed in the control culture.

Microscopy. A BH-2 epifluorescence microscope (Olympus Optical) was used to enumerate the 2 freeliving bacterial types in the cultures where both 253-11 and 407-2 were inoculated. Excitation and emission filters used were, respectively, a $405 \mathrm{~nm}$ band pass and a $455 \mathrm{~nm}$ long pass. After double hybridization, bacteria labeled by AMAC137R (407-2) and stained with fluorescein appeared green and bacteria labeled with

Table 1. Oligonucleotide probes used in this study. All oligonucleotide probes are targeted to the 16S rRNA molecules

\begin{tabular}{|lllll|}
\hline Name & OPD * Name & Specificity & Sequence (5' to 3') & Source \\
\hline AMAC137R & S- $^{*}$-AMAC-0137-a-A-18 & Alteromonas genus & TGTTATCCCCCTCGCAAA & Brinkmeyer et al. (2000) \\
ROSEO536R & S- $^{*}$-ROSEO-0536-a-A-18 & Roseobacter clade & CAACGCTAACCCCCTCCG & Brinkmeyer et al. (2000) \\
ROSEOC536R & S- $^{*}$-ROSEOC-0536-a-A-18 & Competitor for ROSEO536R & CAACGCTATCCCCCTCC & Brinkmeyer et al. (2000) \\
EUB 338R & & Eubacteria & GCTGCCTCCCGTAGGAGT & Amann et al. (1990) \\
& & & \\
\hline
\end{tabular}


EUB 338R (both 253-11 and 407-2) and stained with coumarin appeared blue (Fig. 1). A total of 50 to 500 cells were enumerated per sample. Percentages of 407-2 cells relative to total bacteria (407-2 and 253-11 bacteria) were calculated and specific cell densities were estimated from flow cytometry counts.

To enumerate bacteria attached to dinoflagellates, optical sections of hybridized cells (either with AMAC$137 \mathrm{R}$ or ROSEO536R) were obtained using confocal microscopy: a minimum of 5 dinoflagellates were examined per sampling time. When the density of cells was less than 5 filter $^{-1}$ (Days 0 and 4), all morphologically intact dinoflagellate cells were analyzed. An Olympus Fluoview confocal microscope equipped with 2 lasers was used to study bacterial attachment: an argon-krypton laser (634R-OLYM-A03 Omnichrome, Melles Griot) set at $488 \mathrm{~nm}$ for FITC excitation and a pulsed laser (Coherent mira 900) set at $360 \mathrm{~nm}$ for DAPI and calcofluor excitation. Counts of attached bacteria were obtained by visualizing every optical slice acquired (Biegala et al. 2002). The percentages of attached bacteria cells relative to total bacterial cells was calculated as $B_{\mathrm{a}} \times D /\left[B_{\mathrm{f}}+B_{\mathrm{a}}\right] \times 100$, where $B_{\mathrm{a}}=$ mean number of attached bacteria per dinoflagellate cell, $D=$ number of dinoflagellate cells $\mathrm{m}^{-1}$ and $B_{\mathrm{f}}=$ number of free bacteria $\mathrm{m}^{-1}$.

Toxicity. The toxicity of the Alteromonas and Roseobacter strains 407-2 and 253-11 was verified before inoculation in dinoflagellates cultures and in control cultures using the MNB assay according to Gallacher et al. (1997). Dinoflagellates from control and experimental cultures at stationary phase (Day 34) were harvested by centrifugation $(5 \mathrm{~min}, 2000 \times g)$. Harvested cells (approximately $10^{6}$ cells) were resuspended in $1 \mathrm{ml}$ of $0.05 \mathrm{M}$ acetic acid before storage at $-20^{\circ} \mathrm{C}$. Following thawing of samples, cells were disrupted by the addition of $25 \%$ (w/v) glass beads (150 to $212 \mathrm{~mm}$ diameter, Sigma) and vortex mixed for $5 \mathrm{~min}$. Microscopic examination of cell debris confirmed complete cell disruption. Samples were centrifuged (5 min, $2000 \times g$ ) prior to filtration (Ultrafree centrifugal units, 10000 NMWL [nominal molecular weight limit], Millipore). HPLC analysis of PST was performed according to the method of Franco \& Fernandez-Vila (1993) with amendments detailed in Smith et al. (2001).

\section{RESULTS AND DISCUSSION}

\section{Dinoflagellates and bacterial growth}

Dinoflagellates growth did not seem to be much affected by any of the bacterial combinations tested (Fig. 2A). A lag period was observed only in cultures inoculated with bacteria but the stationary phase was

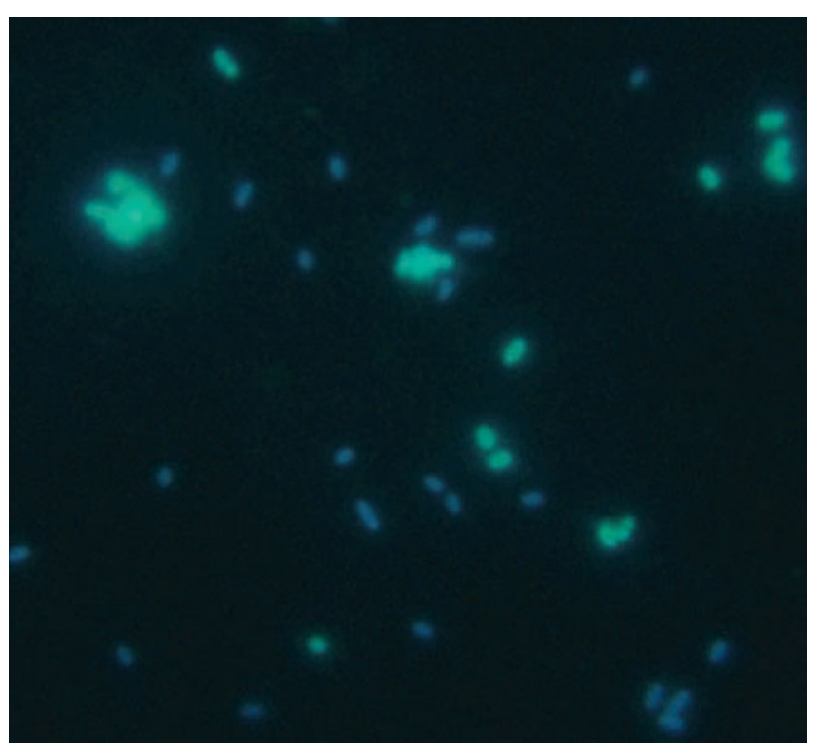

Fig. 1. Epifluorescence microscopy image from a culture containing both Roseobacter strain 253-11 (open arrows) and Alteromonas strain 407-2 (solid arrows) together with Alexandrium tamarense. Cells were sampled at Day 13 and were hybridized with the probe AMAC137R detected using fluorescein tyramide and then with the probe EUB 338R detected with coumarin-tyramide. All bacteria were labeled by the probe EUB 338R (blue color), whereas strain 407-2 was specifically labeled by the probe AMAC137R (green color)

reached at the same time with the same cell densities in all cultures. During the first $15 \mathrm{~d}$ of the experiment, dinoflagellates' influence on bacterial growth was very limited (Fig. 2B-D) and bacteria were able to grow in dinoflagellate-free $\mathrm{f} / 2$ seawater medium almost as well as (Fig. 2B), and sometimes slightly better than (Fig. 2D), when algal cells were present. This suggests that initial bacterial growth was supported by organic matter present in the natural seawater used to prepare the medium but not by organic matter derived from algal cells. In contrast, after Day 15, bacterial growth was strongly affected by the presence of algal cells (Fig. 2B-D). After Day 15, bacteria either disappeared (407-2) or remained at relatively low concentrations (253-11 and 253-11 plus 407-2) in control cultures, whereas after Day 20, bacterial cell densities sharply increased in all 3 cultures containing dinoflagellates (Fig. 2B-D). At this stage, stationary growing dinoflagellates probably stimulated bacterial growth through the production of organic exudates. In cultures where both bacteria were introduced either with or without dinoflagellates, the behavior of each bacterial strain roughly resembled the behavior of the corresponding strain inoculated, respectively, alone in $\mathrm{f} / 2$ medium or alone in a culture of Alexandrium tamarense (Fig. 2D). Thus, both bacterial isolates behaved like many marine 

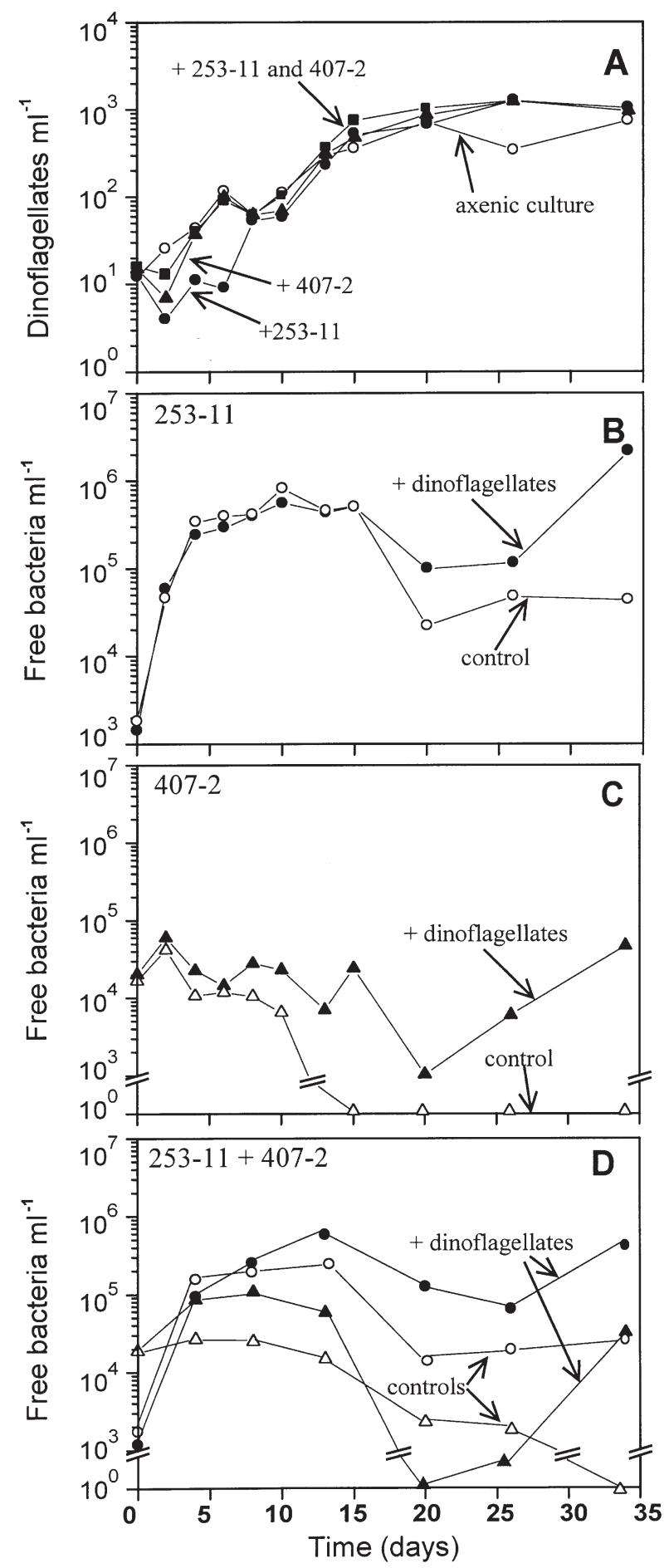

Fig. 2. (A) Changes in Alexandrium tamarense cell densities $(\bullet$, in culture together with the bacterial strain $253-11$; $\mathbf{\Delta}$, in culture together with the bacterial strain $407-2 ; \mathbf{m}$, in culture together with both the bacterial strains 253-11 and 407-2; 0 , in the control axenic culture). Changes in bacterial cell densities: (B) free-living bacterial strain 253-11, respectively, with $(\bullet)$ and without (O) dinoflagellates; (C) free-living bacterial strain $407-2$, respectively, with $(\mathbf{\Delta})$ or without $(\Delta)$ dinoflagellates; (D) both bacterial strains 253-11 and 407-2, with or without dinoflagellates (same symbols as for B and C) bacteria that rely on organic material released by algae (Cole 1982). However, in the literature, the effect of bacteria on the growth of algal species and, conversely, the effect of algae on bacteria, are extremely variable. Cases have been observed of stimulation, but also of inhibition by bacteria on algae (including harmful algal species), or conversely by algae on bacteria as well as cases where none of the organisms showed any response (Cole 1982, Doucette 1995). Culture or environmental conditions may also modulate these interactions. Indeed, independent experiments conducted on A. tamarense and the bacteria 253-11 and 407-2 showed that when larger algal inocula were used, bacteria enhanced algal growth (E. Smith unpubl. data).

\section{Dynamics of bacterial attachment}

Both bacterial strains (Roseobacter strain 253-11 and Alteromonas strain 407-2) were observed attached to the cell surface of morphologically intact dinoflagellates throughout the growth of the dinoflagellate cultures (Fig. 3). Although highly variable among coexisting dinoflagellate cells, the number of attached bacteria per algal cell clearly increased as cultures aged (Figs. $3 \& 4$ ). Bacterial load was rather low in all cases during initial growth $(<10$ bacteria per dinoflagellate until Day 10) but could reach 16, 43 and 80 attached bacteria (average numbers 9,16 and 30 ) at Day 34 in the cultures containing 407-2, 253-11 and 407-2 together with 253-11, respectively (Fig. 4). The percentage of attached bacterial cells relative to total bacterial cells was maximal when dinoflagellates entered stationary phase. At Day 34, 5\% of the 253-11 bacteria and $16 \%$ of the $407-2$ bacteria were found attached when those bacteria were inoculated separately in dinoflagellates cultures. When both bacteria were inoculated together, a maximum of $18 \%$ of the 253-11 and $52 \%$ of the $407-2$ were found attached to dinoflagellate cells. Overall, 407-2 exhibited a more pronounced potential for attachment. This strain also had a tendency to aggregate in clumps (data not shown) while most of the 253-11 bacteria remained free living.

There was no clear relationship between the number of attached bacteria per algal cell and the total number of free bacteria or the number of free bacteria available per dinoflagellate cell (Fig. 4). This shows that bacterial colonization of algal cells is not only constrained by the probability of encounter between both organisms. However, during dinoflagellates' stationary phase, the sharp increase observed in free bacterial cell counts (Fig. 2) was also observed for attached bacteria (Fig. 4). This suggests that the physiological state of dinoflagellates was important for the attachment of those potentially toxic bacteria and that dinoflagellates in stationary phase 

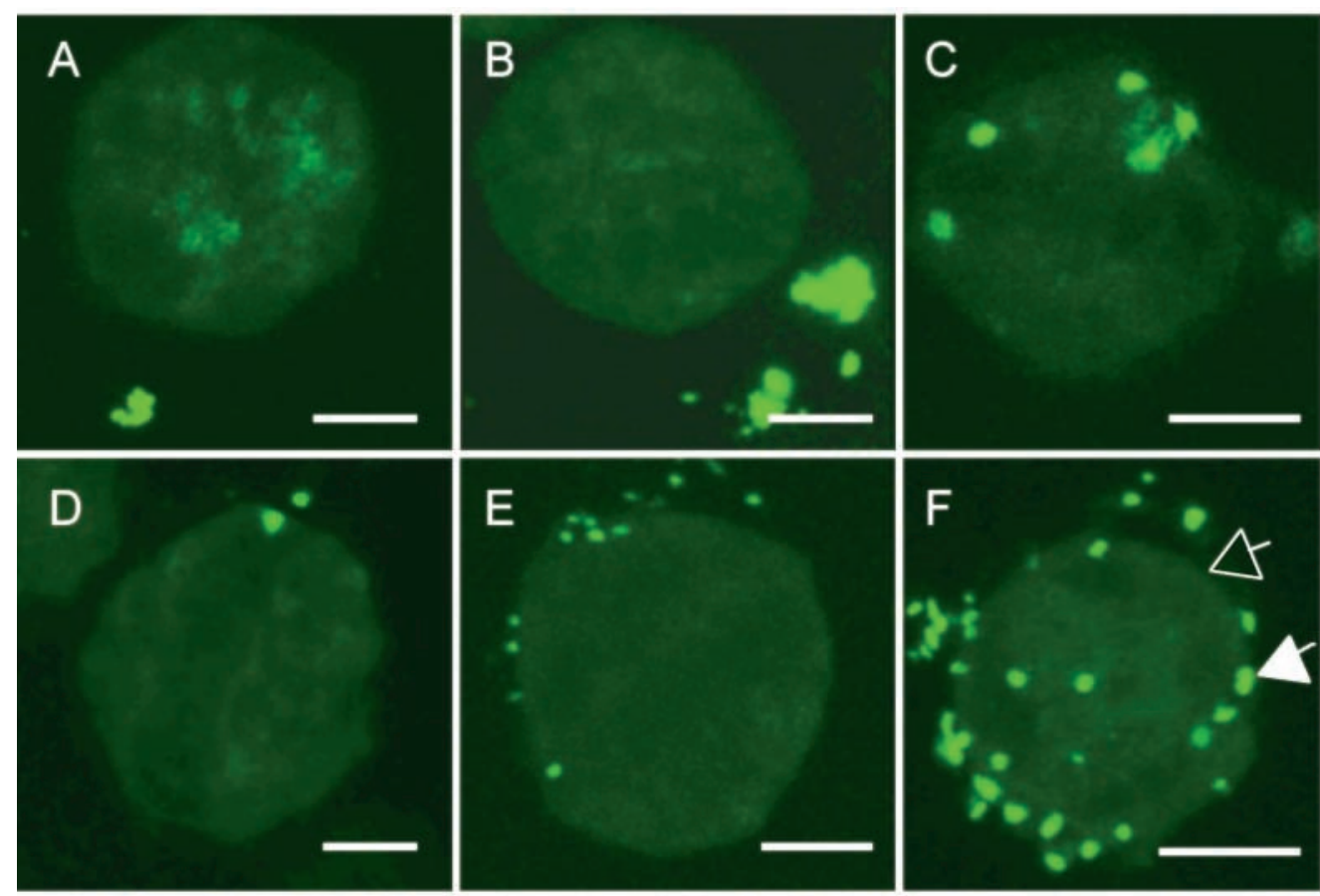

Fig. 3. Confocal laser scanning microscopy images obtained by the superposition of twenty $0.7 \mu \mathrm{m}$ thick optical sections taken through Alexandrium tamarense and its associated microflora. The samples shown were collected in the culture containing both the Alteromonas (407-2) and Roseobacter (253-11) bacterial strains during lag (Day 4; A,D), exponential (Day 13; B,E) and stationary (Day 26; C,F) phases of dinoflagellates growth. Hybridizations were performed, respectively, with the probes AMAC137R to detect specifically the bacterial strain 407-2 (A,B,C) and ROSEO536R to detect specifically the bacterial strain 253-11 (D,E,F). Detection used tyramide-fluorescein. Dinoflagellates autofluorescence (e.g. open arrow in F) is very faint, whereas bacteria are very brightly stained (e.g. solid arrow in F). Scale bars $=10 \mu \mathrm{m}$

stimulated both bacterial growth and attachment. A similar pattern of bacterial attachment has already been observed when non-toxic bacteria were introduced to diatoms, chlorophytes or other non-toxic dinoflagellate cultures (Bell \& Mitchell 1972, Kogure et al. 1982, Albright et al. 1986). In this respect, the general behavior of these toxic or potentially toxic bacteria towards phytoplankton cells was similar to the behavior of other marine bacteria. Ageing phytoplankton cells probably release increasing amounts of exudates through porous membranes and cell walls (Fogg 1983). The physical associations and kinetics of the association could result from chemotactic responses of the bacteria to algal exudates (Bell \& Mitchell 1972, Albright et al. 1986) and/or from an increased bacterial potential for attachment (through the production of exopolymers for example). Attachment is probably beneficial for bacterial growth since these algal exudates represent sources of organic carbon for bacteria (Paerl 1976, Azam et al. 1995).

\section{Toxicity tests}

Both the Alteromonas strain 407-2 and Roseobacter strain 253-11 are capable of SCB toxin production and the chemical nature of the toxin produced by $407-2$ was determined as PST by capillary electrophoresismass spectrometry (Gallacher et al. 1997, Gallacher \& Smith unpubl. data). However, only 407-2 produced SCB toxins when tested using the MNB assay prior to this study (data not shown), while strain 253-11 did not consistently demonstrate toxicity. In our study, although bacterial attachment was clearly occurring, addition of the 2 bacteria either individually or in combination did not induce any detectable PST production (detection limit for gonyautoxins 1, 2, 3 and 4, saxitoxin and neosaxitoxin on the column were respectively $0.28,0.33,0.08,0.12,0.57$ and $3.77 \mathrm{ng}$ ) in the stationary dinoflagellate cultures. Previous experiments involving inoculation of toxigenic or non-toxigenic bacteria into axenic toxic dinoflagellate cultures suggested that bacteria enhanced toxin production via attachment: indeed, inoculation of viable bacteria considered to be toxigenic into an axenic culture of the toxic dinoflagellate from which they were isolated (Alexandrium lusitanicum) enhanced toxin production, whereas addition of bacteria in dialysis tubing (which prevented attachment) was inefficient (Doucette \& Powell 1998). Similarly, experiments conducted on a toxic non-axenic strain of the benthic dinoflagellate Ostreopsis lenticu- 


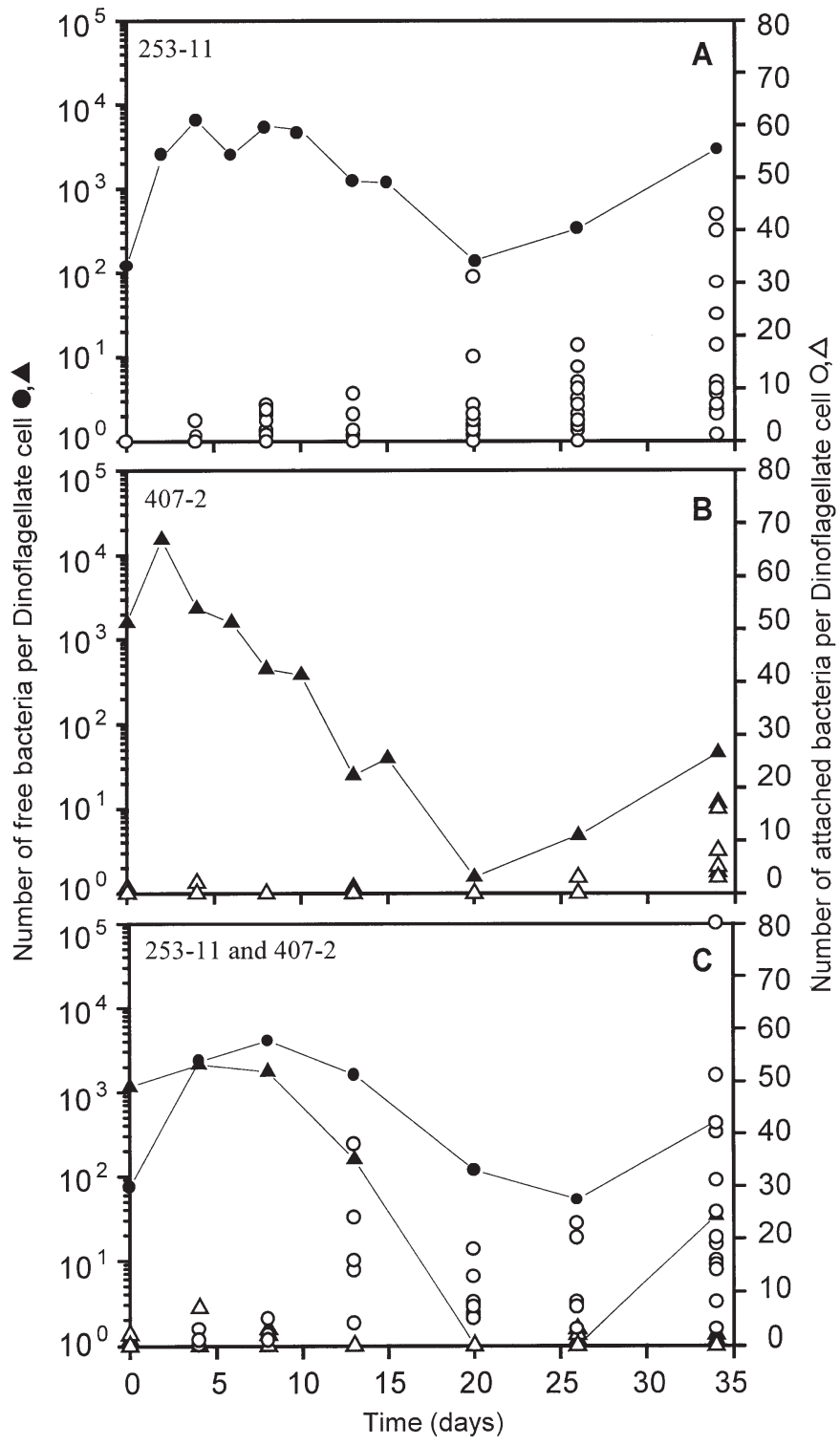

Fig. 4. Changes in the number of free and attached bacteria per dinoflagellate cell. For attached bacteria, each symbol represents a data point for a single dinoflagellate cell and data obtained for each dinoflagellate analyzed were plotted. Experimental culture containing (A) dinoflagellates and Roseobacter strain 253-11: free (•) and attached (O) 253-11; (B) dinoflagellates and Alteromonas strain 407-2: free (\) and $(\Delta)$ attached 407-2; (C) dinoflagellates and both strains 407-2 and 253-11: free $(\bullet)$ and attached (0) 253-11 and free $(\boldsymbol{\Delta})$ and $(\Delta)$ attached $407-2$

laris showed that marked increases in the proportion of non-toxic bacteria directly associated with the surfaces of algal cells were correlated with the development of peak dinoflagellate toxicity (Tosteson et al. 1989).

In conclusion, we have shown by a direct approach that toxigenic bacteria are able to attach to Alexandrium tamarense in culture and that this mainly occurs when the culture enters stationary growth phase. However, attachment of those bacteria does not necessarily induce toxin production in A. tamarense. This does not support the hypothesis that toxic bacteria could simply control toxin production by attachment to particle surfaces such as eukaryotic organisms (Doucette et al. 1998). Attachment may still be crucial to induce and/or modulate toxin production by bacteria and/or dinoflagellates in the environment. Other factors such as nutrient availability (Kodama 1990, Doucette \& Trick 1995) or strain-to-strain specificity (Imam et al. 1984) may also be important. In this context, our study shows that the use of a combination of sophisticated microscopy techniques with nucleic acid probes should permit deep insights, at the cellular level, into specific physical interactions between phytoplankton and bacteria. Given the important ecological implications of those interactions, for example on population dynamics or toxin production, such studies are clearly justified.

Acknowledgements. We thank Susan Gallacher for providing us with the bacterial strains, Jean-François Lennon for assistance with CLSM and Florence Le Gall for assistance with dinoflagellate cultures. This study was supported by the European Grant FAIR No. CT96-1558.

\section{LITERATURE CITED}

Albright LJ, McCrae SK, May BE (1986) Attached and freefloating bacterioplankton in Howe Sound, British Columbia, a coastal marine fjord-embayment. Appl Environ Microbiol 51:614-621

Alm EW, Oerther DB, Larsen N, Stahl DA, Raskin L (1996) The oligonucleotide probe database. Appl Environ Microbiol 62:3557-3559

Amann RI (1995) In situ identification of micro-organisms by whole cell hybridization with rRNA-targeted nucleic acid probes: molecular microbial ecology manual. Kluwer Academic, Dordrecht, p 1-15

Amann RI, Binder BJ, Olson RJ, Chisholm SW, Devereux R, Stahl DA (1990) Combination of 16S rRNA-targeted oligonucleotide probes with flow cytometry for analyzing mixed microbial populations. Appl Environ Microbiol 56: 1919-1925

Amann RI, Zarda B, Stahl DA, Schleifer KH (1992) Identification of individual prokaryotic cells by using enzymelabeled, rRNA-targeted oligonucleotide probes. Appl Environ Microbiol 58:3007-3011

Azam F (1998) Microbial control of oceanic carbon flux: the plot thickens. Science 280:694-696

Azam F, Smith DC, Long RA, Steward GF (1995) Bacteria in oceanic carbon cycling as molecular problem. In: Joint I (ed) Molecular ecology of aquatic microbes. SpringerVerlag, Berlin, p 39-54

Bell W, Mitchell R (1972) Chemotactic and growth responses of marine bacteria to algal extracellular products. Biol Bull 143:265-277

Biegala IC, Kennaway G, Alverca E, Lennon JF, Vaulot D, Simon N (2002) Identification of bacteria associated with dinoflagellates (Dinophyceae) Alexandrium spp. using 
tyramide signal amplification-fluorescent in situ hybridization) and confocal microscopy. J Phycol 38:404-411

Blackburn N, Fenchel T, Mitchell J (1998) Microscale nutrients patches in planktonic habitats shown by chemotactic bacteria. Science 282:2254-2256

Brinkmeyer R, Rappé M, Gallacher S, Medlin L (2000) Development of clade- (Roseobacter and Alteromonas) and taxon-specific oligonucleotide probes to study interactions between toxic dinoflagellates and their associated bacteria. Eur J Phycol 35:315-329

Cole J (1982) Interactions between bacteria and algae in aquatic ecosystems. Annu Rev Ecol Syst 13:291-314

Cole JJ, Findlay S, Pace ML (1988) Bacterial production in fresh and saltwater ecosystems: a cross-system overview. Mar Ecol Prog Ser 43:1-10

Dantzer WR, Levin RE (1997) Bacterial influence on the production of paralytic shellfish toxins by dinoflagellate algae. J Appl Microbiol 83:464-469

Doucette GJ (1995) Interaction between bacteria and harmful algae: a review. Nat Toxins 3:65-74

Doucette GJ, Powell CL (1998) Algal bacterial interactions: can they determine the PSP-related toxicity of dinoflagellates? In: Reguera B, Blanco J, Fernandez ML, Wyatt T (eds) Harmful algae. Intergovernemental Oceanographic Commission, UNESCO, Santiago de Compostella, p 406-409

Doucette GJ, Trick CG (1995) Characterization of bacteria associated with different isolates of Alexandrium tamarense. In: Lassus P, Arzul G, Erard E, Gentien P, Marcaillou-LeBaut C (eds) Harmful marine algal blooms. Lavoisier Intercept Ltd, Paris, p 33-38

Doucette GJ, Kodama M, Franca S, Gallacher S (1998) Bacterial interaction with harmful algal bloom species: bloom ecology, toxigenesis, and cytology. In: Anderson DM, Cembella AD, Hallegraeff GM (eds) Physiological ecology of harmful algal blooms. Springer-Verlag, Berlin, p 619-647

Fogg GE (1983) The ecological significance of extracellular products of phytoplankton photosynthesis. Bot Mar 26: $3-14$

Franco JM, Fernandez-Vila P (1993) Separation of paralytic shellfish toxins by reversed phase high performance liquid chromatography, with postcolumn reaction and fluorimetric detection. Chromatographia 35:613-620

Gallacher S, Flynn KJ, Franco JM, Brueggemann EE, Hines HB (1997) Evidence for production of paralytic shellfish toxins by bacteria associated with Alexandrium spp. (Dinophyta) in culture. Appl Environ Microbiol 63:239-245

Gurung T, Urabe J, Nakanishi M (1999) Regulation of the relationship between phytoplankton Scenedesmus acutus and heterotrophic bacteria by the balance of light and nutrients. Aquat Microb Ecol 17:27-35

Hold GL, Smith EA, Birkbeck TH, Gallacher S (2001) Comparison of paralytic shellfish toxin (PST) production by the dinoflagellates Alexandrium lusitanicum NEPCC 253 and Alexandrium tamarense NEPCC 407 in the presence and absence of bacteria. FEMS Microbiol Ecol 36:223-234

Holmström C, Kjelleberg S (1999) Marine Pseudoalteromonas species are associated with higher organisms and produce biologically active extracellular agents. FEMS Microbiol Ecol 30:285-293

Imam SH, Barde RF, Tosteson TR (1984) Specificity of marine microbial surface interactions. Appl Environ Microbiol 48: 833-839

John EH, Flynn KJ (1999) Amino acid uptake by the toxic dinoflagellate Alexandrium fundyense. Mar Biol 133:11-19

Kodama M (1990) Possible links between bacteria and toxin production in algal blooms. In: Granéli E, Sundström B, Edler L, Anderson DM (eds) Toxic marine phytoplankton.
Elsevier Scientific Publishers, New York, p 52-61

Kogure K, Simidu U, Taga N (1982) Bacterial attachment to phytoplankton in sea water. J Exp Mar Biol Ecol 56:197-204

Lafay B, Ruimy R, Rausch de Traubenberg C, Breittmayer V, Gauthier MJ, Christen R (1995) Roseobacter algicola sp. nov., a new marine bacterium isolated from the phycosphere of the toxin-producing dinoflagellate Prorocentrum lima. Int J Syst Bacteriol 45:290-296

Lewis J, Kennaway G, Franca S, Alverca E (2001) Bacterial dinoflagellate interactions: investigative microscopy of Alexandrium spp. (Gonyaulacales, Dinophyceae). Phycologia 40:280-285

Manage PM, Kawabata Z, Nakano SI (2000) Algicidal effect of the bacterium Alcaligenes denitrificans on Microcystis spp. Aquat Microb Ecol 22:111-117

Manz W, Amann R, Ludwig W, Wagner M, Schleifer KH (1992) Phylogenetic oligodeoxynucleotide probes for the major subclasses of proteobacteria: problems and solutions. Syst Appl Microbiol 15:593-600

Marie D, Partensky F, Jacquet S, Vaulot D (1997) Enumeration and cell cycle analysis of natural populations of marine picoplankton by flow cytometry using the nucleic acid stain SYBR Green I. Appl Environ Microbiol 63: 186-193

Osada M, Stewart JE (1997) Gluconic acid/gluconolactone: physiological influrences on domoic acid production by bacteria associated with Pseudo-nitzschia multiseries. Aquat Microb Ecol 12:203-209

Paerl HW (1976) Specific associations of the bluegreen algae Anabaena and Aphanizomenon with bacteria in freshwater blooms. J Phycol 12:431-435

Rausch de Traubenberg C, Lassus P (1991) Dinoflagellate toxicity: are marine bacteria involved? Evidence from the literature. Mar Microb Food Webs 5:205-226

Schönhuber W, Zarda B, Eix S, Rippka R, Herdman M, Ludwig W, Amann R (1999) In situ identification of cyanobacteria with horseradish peroxidase-labeled, rRNA-targeted oligonucleotide probes. Appl Environ Microbiol 65: $1259-1267$

Silva ES (1990) Intracellular bacteria: the origin of dinoflagellate toxicity. J Environ Pathol Toxicol Oncol 10:124-128

Silva ES, Franca S (1985) The association dinoflagellatebacteria: their ultrastructural relationship in two species of dinoflagellates. Protistologica 21:429-446

Silva ES, Sousa I (1981) Experimental work on the dinoflagellate toxin production. Arq Inst Nac Saúde 6:381-387

Smith EA, Grant F, Ferguson CMJ, Gallacher S (2001) Biotransformation of paralytic shellfish toxins (PST) by bacteria isolated from bivalve molluscs. Appl Environ Microbiol 67:2345-2353

Tosteson TR, Ballantine DL, Tosteson CG, Hensley V, Bardales AT (1989) Associated bacterial flora, growth, and toxicity of cultured benthic dinoflagellates Ostreopsis lenticularis and Gamberdiscus toxicus. Appl Environ Microbiol 55:137-141

Urdea MS, Warner BD, Running JA, Stempien M, Clyne J, Horn T (1988) A comparison of non-radioisotopic hybridization assay methods using fluorescent, chemiluminescent, and enzyme labeled oligodeoxyribonucleotide probes. Nucleic Acids Res 16:4937-4956

Vaqué D, Duarte CM, Marrassé C (1990) Influence of algal population dynamics on phytoplankton colonization by bacteria: evidence from two diatom species. Mar Ecol Prog Ser 65:201-203

Worm J, Sondergaard M (1998) Dynamics of heterotrophic bacteria attached to Microcystis spp. (Cyanobacteria). Aquat Microb Ecol 14:19-28

Submitted: July 16, 2001; Accepted: April 12, 2002

Proofs received from author(s): July 15, 2002 